\title{
Documento preliminar sobre descentralização
}

\section{José Menezes Senna (*) \\ Thereza Lobo \\ rnlaboracan: \\ Midjam da fonseca Mhagso}

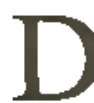
entre as grandes açōes preconizadas para a Reforma da Administração Pública Federal, encon tra-se a Descentralização - esforço que há de se enfrentar neste Pais na busca incessante de permitir à sociedade brasileira au ferir dos serviços públicos de forma equilativa, indiscriminada e, sobretudo, assumindo a sua parcela de responsabilidade social e politica, diante das decisōes tomadas pelas esferas de governo.

É importante assinalar que não há experiência histórica no Pais que permita o balizamento de um processo de descentralização efetivo. A tradição da administraçāo pública brasileira caracteriza-se basicamente por processos de desconcentração e não de descentralização.

Há que se diferenciar a atual proposta de estratégia governamental, dos procedimentos adotados em periodos anteriores, os quais, na verdade, nāo passaram de pura desconcentração administrativa. Embora importante, a desconcentração não pode ser confundida com a descentraljzação, por envolver, esta última, ques- tôes de ordem política mais profunda.

Cabe ainda destacar que a descentralizaçāo deve ser entendida a par(ir de três vertentes: 1) entre esferas de governo; 2) da administração direta para a indireta; e 3) do setor público para o setor privado. No último caso, encontram-se em andamento os trabalhos da Comissāo de Privatizaçāo, na SEPLAN/PR, tendo por objetivo a definiçāo de parầmetros e o encaminhamento das açōes respectivas.

Neste sentido, este documento tratará exclusivamente da descentralização no âmbito interno da açâo do Estado brasileiro, em seu sentido amplo.

\section{Principins Norteadores da Descenlm- lizaçāo}

Para que o processo de descentralizaçāo encontre um caminho seguro para a eficácia da açāo do poder público, na direção da equanimidade e da universalidade da prestaçāo dos serviços, devem ser levados em consideração determinados princípios norteadores permeando todo o processo. Sāo eles:

(•) José Menezes Senna é engenhelro civil e administrador de empresa, secretário-geral adjunto do Ministér do dos Transporles, membro da Comissáo da Felorma, presidenle da Comıssåo Especial de Descentralizaçăo e vice-presidente da Comissåo Nacional de Facilitaçăo do Comérıco Exterior.

Thereza Lobo es socıóloga, membro da Comıssåo da Felarma Tributária e Descentralizaçăo, membro da Câmara $V$ da Comıssäo da Relorm, assessora lécnica da Fundaçăo Educar e do Ibam.

\section{- Flexibilidade}

Toda e qualquer ação governamental a ser descentralizada deve ser presidida por uma flexibilidade inter e intra-regional. Há que se deixar de lado o discurso e atacar-se de frente a. realidade da diferenciaçāo econômica, política e social do espaço nacio nal. As peculiaridades regionais e lo cais devem ser obrigatoriamente levadas em consideraçāo quando o processo de descentralizaçāo for encaminhado. Fstados e Municípios nào podem mais ser Iratados de forma homogênea e simétrica, seja pela legislaçāo ou pelas agências ou programas governamenlais. As realidades técnicas, financeiras e politicas sāo distintas e, como tal, devem ser trabalhadas.

\section{- Gradualismo}

Dentro da mesma linha de respeito às peculiaridades regionais e locais, o processo de descentralização deve ser encaminhado de forma gradual, no tempo e no espaço. A real capacidade de resposta dos governos subnacionais deve ser avaliada, sem subestimação, ou superestimação. A flexibilidade aqui se conjuga com o gradualismo, pois uma mesma esfera de governo pode estar apta a receber determinados encargos hoje e não poder receber outros.

\section{- Progressividade}

Assume-se o sentido estrito do conceito de processo no caso da descentralização, ao definir-se o princí- 


\section{IDÉIAS}

pio da progressividade. A Mlexibilida. de e o gradualissmo nāo implicam esrancamento. Ao contrário, a dinâmica do processo de descentralizaçāo exige que ele seja progressivo ou seja, que cada vez mais, a partir do estabclecimento de prioridades, funções e encargos sejam repassados. Com is10 quer-5e dizer da necessidade constante de preparação dos niveis de governo para o recebimento de responsabilidade.

\section{- Transparência no Processo Decisório}

O processo de descentralização se norteia por um conjunto de decisōes governamentais de alocaçāo de recursos que deve ser acessivel àqucles que as execurarão, bem como aos que serão beneficiários da açāo do poder público. O acesso deve ser garantido através da mais ampla divulgaçāo do processo de tomada de decisōes em si, como rambém da possibilidade de participaçāo no mesmo. A abertura do processo decisório é critério definitivo no sentido da democratização do Esrado brasileiro. Isso é verdade para qualquer insıância de governo.

\section{- Controle Social}

O processo de descentralização, se se o quer instrumento de democratização, precisa incorporar mecanismos de acompanhamento, supervisão e avaliação, outros, que não os tradicionalmente encontrados na experiência da administração pública brasileira. A supervalorizaçāo de mecanismos formais de controle, extremamente burocratizados, não garantiu até agora a eficácia e a justiça na prestação de ação governamental. Nesse sentido, coloca-se como fundamental a criaçào de mecanismos que possibilitem à população o exercício da cobrança e físcalizzação da açāo do poder público. Conjugada com a Iransparência do processo decisório, o controle da suciedade organizada (Associaçōes Comunitárias, Órgãos de Classe, etc.) permirírá desenvolver o sentido da responsabilidade civica da população. Is.so não exclui a manutenção ou reformulaçāo, quando necessária, dos mecanismos formais de controle à disposição da administraçāo pública, desde que baseados e ga-

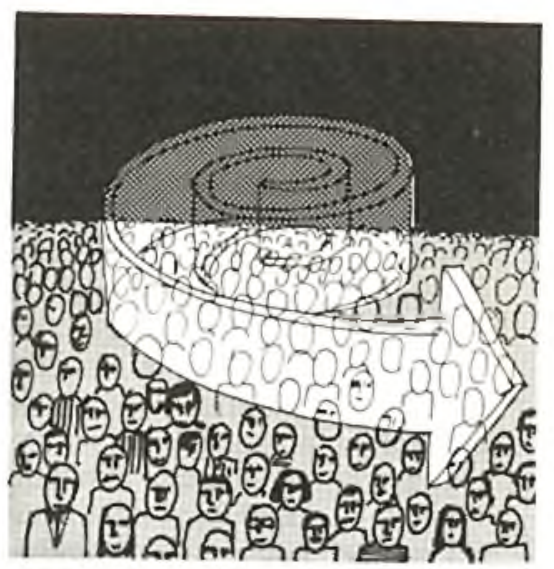

\section{$A$ descentralização, para ser um instrumento de} democratizaçāo, precisa incorporar mecanismos de zcompanhamento, avaliação

e supervisão que não os tradicionalmente adotados na experiência da administração pública do País. A supervalorização de mecanismos formais de controle näo garantiu, alé agora, eficácio na ação governamental.

rantidos em critérios desburocracizantes capazes de agilizar e tornar transparentes as decisões tomadas e as execuçōes empreendidas.

\section{Instrumenlos/Mecanismos do Pro- cesso de Descenıralização}

A oportunidade e a urgência do processo de descentralizaçāo fazem com que seja fundamental uma reflexão sobre a operacionalizaçāo do mesmo, repensando os mecanismos e instrumentos atualmente disponiveis, visando seu aprimoramento ou a criação de alternativas.

Em conseqüência, cabe repensar a estrutura politico-institucional responsável pelo atual sistema de distribuição de competências, entre esferas de governo que, consensualmente, nāo aringe as necessidades da sociedade brasilcira. O que vige é uma polarizaçāo entre as compclências exclusivas, geralmente atribuidas à Uniāo. e as competências concorrenles, em que todas as unidades de governo estão mais ou menos habilitadas a executar funçōes em determinadas áreas.

Como é sobejamente conhecido, a indefinição de fronteiras funcionais gera inúmeros problemas, tais como, duplicação de esforços e recursos, prestaçāo inadequada dos serviços, não responsabilização de agências governamentais, conflitos institucionais, etc. Dessa maneira, o processo de descentralização deve contribuir para a melhor definição da divisāo de competências governamentais. Isso nāo significa, entretanto, que a questão se resolva através de modelos teóricos. Os princípios norteadores da descenIralização justificam tal impossîbilidade.

É necessário portanto, refletir sobre as funções próprias de cada esfera de governo, já tradiconalmente incorporadas ao aparato político-instilucional e, de forma gradual, progressiva e flexível, reestruturar a divisāo de competências através da descentralização. Nesse momento cabe repensar e resgastar o conceito e a prática da função delegada como o mecanismo indutor por excelência, para implantar e implementar a descentralizaçāo.

Através da mesma delaga-se a um certo nivel de governo a possibilidade ou o poder de gerir, e executar a prestação de um determinado serviço público que antes era atribuido a outra esfera de governo, geralmente superior. A delegaçāo é temporária e se suporta num acompanhamento e supervisão constante da esfera governamental que delega o serviço. Tal função delegada pode, em dependendo da performance do governo receptor, trasnformar-se em competência própria ou exclusiva, ou mesmo retonar ao nivel de governo antes responsável, no caso do nāo cumprimento adequado da prestaçāo de serviço delegado. Os instrumentos legais mais indicados são as Leis, elaboradas pelas diferentes esferas, para diferentes tipos de delegação de funções.

Outro mecanismo que deve ser recuperado refere-se à compelência supletiva. No caso, duas ou mais unidades de governo acordam para a prestação de um determinado serviço, levando em consideração critérios de custo, capacidade de operaciona- 


\section{IDÉIAS}

lização e amplitude de beneficios a serem atingidos, entrc outros. Esse tipo de arranjo institucional é o que mais se aproxima da essência do sistema federalista que pressupōe o pacto e a negociaçāo entre distintas esferas de governo. Toda possibilidade e a necessidade de criaçāo ou recuperação de novos mecanismos não exclui o aproveitamento de instrumentos hoje disponiveis à administração pública: convênios, contratos, portarias, protocolos, cartas de adesāo, etc. Esse aparato nāo deve ser desprezado, mas antes sofrer um processo de normatizaçāo, respeitando as peculiaridades das diferentes ações governamentais, buscando superar as limitações que hoje o fazem vulnerável enquanto instrumentos de açāo políticogovernamental : o risco do clientelismo politico, a descontinuidade temporal e espacial, o arbírio de definições de política governamental tomadas por uma esfera supcrior de governo, seja federal ou estadual.

\section{Diretrizes}

A reversão do movimento centralizador do Estado, dentro dos princípios enunciados, através da redução do peso do setor público sobre a empresa privada e a sociedade, em geral, e, dentro do próprio governo, pela transferência de funções, atribuiçôes e competências da União para os estados e municípios, implica um profundo reexame e debate sobre as funçōes que a sociedade deseja sejam exercidas pelo governo, em seus diversos niveis, tendo como conseqüência a revisão dos mecanismos fiscais e financeiros de apropriaçāo, transferência e alocaçāo de recursos.

Essa reorientação de tendências, que deverá resultar numa reformulação estrutural do governo e da sociedade pode ser iniciada de imediato, independentemente de uma reforma tributária mais ampla, tais como: convênios, delegação de competência, recuperaçāo do instituto da funçāo delegada, da competência supletiva e da privatização de empresas públicas, dentro das seguintes diretrizes:

- A Uniāo deverá concentrar-se em funções normativas, formulando as grandes politicas de âmbito nacional nos setores básicos de infra-estrutura econô. mica e de necessidades básicas, repassando as demais para o setor privado e, quando for a caso, para os governos estaduais e locais.

- A Uniāo deverá extinguir ou reformular órgãos e entidades cujos custos decorram, predominantemente, de pagamentos de pessoal, excetuadas as Forças Armadas, o Fisco, as Relaçōes Exteriores e outras funçōes inerentes ao poder de polícia, bem como aqueles órgãos prestadores de serviços imprescindiveis.

- Quando houver superposiçāo competitiva ou redundante entre dois ou mais órgãos e entidades federais, prevalecerá a ju-

\section{É necessário impor uma reorientação que leve a uma reformulaçâo} estrutural do Governo e da Sociedade, que pode ser iniciada de imediato, independentemente de uma reforma tributária mais ampla, com a utilizaçâo de convênios, recuperaçâo do instituto da funçäo delegada, do competência supletiva e privatização de empresas públicas.

risdição de um só, sendo extintos ou reformulados os demais.

- Deverāo ser desativadas ou eliminadas as empresas públicas ou sociedades de economia mista cujas funçōes se caracterizem como de simples repassadoras de recursos financeiros.

Operacionalização do processo de Descentralizaçãa

\subsection{Para o Setor Privado}

A Comissāo de Privalizaçāo da SEPLAN/PR está encaminhando os trabalhos visando à progressiva devolução de atividades empreendidas pe- lo setor público à iniciativa privada. As atividades dessa Comissāo atendem, portanto, à exigência de uma das vertentes do processo de descentralização.

\subsection{Entre Esferas de Governo}

O processo de descentralizaçāo que se pretende implementar tem como objetivo a passagem progressiva, gradual e flexível de ações atć cntāo sob responsabilidade do governo federal para as esferas estaduais c municipais. Nesse sentido, incluem-se nesse processo órgãos da administraçāo direla e indireta federal que aprcsentem ações que possam ser executadas dirctamente pelas administraçōes estaduais e locais com melhores resultados.

Cabe destacar que o processo de descentralizaçāo das ações federais traz em si uma caracteristica de transitoriedade, na medida em que esperase que progressivamente os governos estaduais e locais assumam as responsabilidades repassadas de forma definitiva, como competência próprias. Dessa forma, à medida que o processo for avançando, estará se configurando uma redefinição da distrihuiçān de competências governamenlais até então existentes.

Pode-se, portanto, sugerir um elenco de ações concretas que visam a iniciar o processo de descentralizaçāo com base nos principios norteadores antes referidos. A tentativa de elaborar uma metodologia de açōes descentralizadoras justifica-se exclusivamente, pela necessidade de ordenamento do processo, nāo significandn arientaçāo righida.

Assim sendo, as etapas a seguir mencionadas devem ser vistas como sugestões para o encaminhamento do processo que certamentc assumirá caracteristicas específicas em cada agência governamental.

a) Identificaçāo de Programas e Açōes Passíveis de Descentralização.

Nessa clapa deve-se procurar identificar as situações que scrão objeto de ação descentralizadora. Dada a característica de 1 ransitoriedade do processo, deve-se levar em conta perspeclivas de curto, médio e longo prazos, buscando com isso atender à diversi- 


\section{IDÉIAS}

ficaçāo dos programas e ações e das realidades estaduais e locais que receberão as atribuições a serem definidas.

Em termos de curto prazo (1986), sugere-se que o Programa de Prioridades Sociais sirva de base para a identificaçāo dos programas passíveis de descentralização. Isso não impede entretanto, que outros programas e ações especificas dos Ministérios e entidades descentralizadas possam ser desenvolvidas com a mesma orientaçāo.

A médio e longo prazo deverão ser levados em consideraçāo programas e ações já em andamento e que possam ser redirecionados para a descenIralizaçāo e os que desde o inicio de sua implementaçāo serão encaminhados de forma descentralizada.

A identificaçāo dos programas e ações pode orientar-se através de dois critérios básicos, que certamente nāo serão os únjicos:

- natureza espacial dos programas de ações: identificação da populaçāo beneficiária do programa ou açāo, se limitada ao âmbito do municipio, de parte ou todo a território estadual, ou de parte ou todo o território nacional (mais de um Estado).

- compalihilizaçāo com programas e/ou projelos oriundos dos governos estaduais e municipais: deverão ser priorizados para a descentralização aqueles programas e açōes federais que incorporem em seus objetivos os interesses gerados pelas rcalidades regionais e locais. Para tanto será necessário um mapeamento desses programas/projeros já recebidos pelo governo federal e sua integraçâo ao processo de descentralização. Cabe ressaltar que devem haver programas que sejam indutores de uma açāo governamental que se considera relevante, expressando politicas nacionais com reflexos regionais e locais.

O produto dessa erapa deve concretizar-se numa listagem dos programas e ações federais a serem descenıralizados no curto, médio e longo prazo. b) Elaboração de Critérios para Progressiva Transferência de Responsabilidades entre esferas de Governo.

Cada programa ou açāo identificada na etapa anterior deve elaborar critérios de transferência progressiva de responsabilidades para as esferas esraduais e municipais, garantindo um grau de flexibilidade adequado às respectivas realidades a serem atendidas. Serão definidos aí os seguintes aspectos:

- unidades de governo envolvidas: se o governo federal e estadual; se governo federal e municipal;

Em termos de curto prazo,

o Programa de Prioridades

Sociais pode servir de

base para identificar-se

os programas passiveis de

descentralizaçâo. A médio

e longo prazos, deverão

ser levados em conta os

programas e açôes jé em

andamento e que possam

ser redirecionados para

a descentralização,

com base em critérios

previamente definidos.

se as três esferas simultanea mente.

- responsabilidades a serem distribuídas: atribuição de cada esfera de governo envolvida no programa; se prestação de assistência técnica; se planejamento, execução, operaçāo/manutenção; e se acompanhamen10/avaliação dos projetos a serem implementados. Ao governo federal caberá sempre a res. ponsabilidade do repasse de recursos financeiros. As demais arribuiçōes vão variar dependendo dos objetivos a serem atingidos e da capacidade operacional das unidades receptoras. É necessário nessa etapa levar em consideraçāo mecanismos de contrapartida adequa- dos às condições das realidades regionais e locais e seus reflexos para tais administrações. É importante ainda que tipologias de municípios funcionem como orientadoras da diversificaçāo de responsabilidades atribuídas em cada programa ou ação.

c) Identificação de Mecanismos para Transferência de Responsabilidades.

Dependendo das caracteristicas de cada programa ou açāo descentraljzada, serão definidos os mecanismos a serem utilizados para a transferência de responsabilidade às esferas inferiores de governo. Sugere-se que o repasse direto de recursos a fundo perdido deve ser priorizado. Por outro lado, devem ser pensado sem mecanismos que definam as atribuiçōes especificas de cada esfera de governo. E necessário levar em conta que os mesmos prevejam a progressiva incorporaçāo dos recursos e responsabilidades a serem repassados como recejtas e atribuições próprias, contribuindo portanto para a furura redefiniçāo do sistema de transferências constitucionais e do sistema de tributação nacional. Ainda nessa etapa inclui-se o dever do Governo Federal de elaborar diretrizes gerais, não impositivas, sobre a alocação dos recursos e responsabilidades a outras esferas de governo. Cabe retomar nessa etapa o que foi dito anteriormente sobre a necessidade de normatização do instrumento existente e a criaçāo de novos mecanismos, tais como a função delegada.

\section{d) Flaboraçāo de Plano de Acompa nhamento, Supervisão e Avaliação.}

Todo e qualquer programa de ação a ser descentralizado deve prever um sistema de acompanhamento, supervisão e avaliaçāo. Retoma-se aqui, necessariamente, a divisão de responsabilidades estabelecida na elapa b. Ao mesmo tempo é nessa etapa que deve dar-se ênfase à criação de mecanismos que possibilitem a intervenção da sociedade organizada no acompanhamento, supervisão e avaliaçāo dos programas e açōes federais (controle social), sem excluir os controles formais já existentes, desde que baseados em critérios desburocratizantes. 